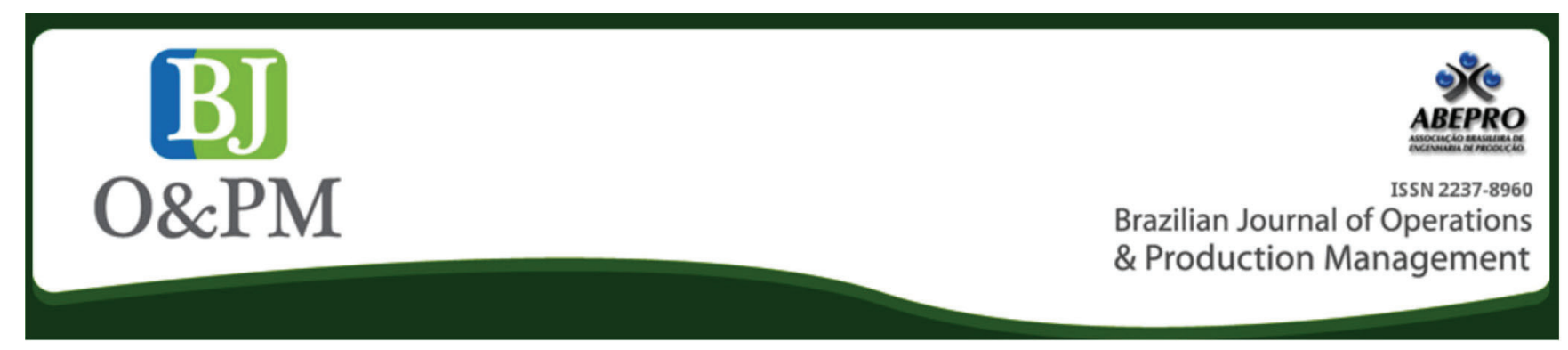

\title{
SIMILARITY MODELING WITH IDEAL SOLUTION FOR COMPARATIVE ANALYSIS OF PROJECTS IN THE CONTEXT OF THE ADDITIONAL BRICS PROPOSAL
}

\section{Rosangela de Lima Gonçalves Saisse \\ rosangela.saisse@gmail.com Brazilian Naval School, Rio de Janeiro, Rio de Janeiro, Brazil.}

\section{Gilson Brito Alves Lima} gilson@latec.uff.br Fluminense Federal University UFF, Niterói, Rio de Janeiro, Brazil.

\begin{abstract}
Goal: Based on the project called "Additional BRICS", this study aims to present an analysis on the topics Human Capital and Innovation, discussed at the X BRICS Summit, involving four countries - Argentina, Indonesia, Jamaica and Turkey - invited to participate in the Project which is intended for cooperation between emerging countries.

Design/ Methodology / Approach: In this context, from the modeling of the indicators provided by the Global Human Capital and Innovation Reports, published annually by the World Economic Forum (WEF) and the World Intellectual Property Organization (WIPO), during the period from 2015 to 2017 an analysis of the performance of the invited countries was carried out with the methodological support of the TOPSIS (Technique for Ordering Performance by Similarity to the Ideal Solution).

Results: The analysis of the results by the method, among the dimensions considered, highlighted Turkey in the Human Capital and Innovation issues, considering the global market.

Limitations of investigations: This research had as main limitations the data from the selected global indicators and the context of the emerging countries that were invited to participate in the BRICS Additional project.

Practical implications: This study provides parameters for decision-making by executives and legislators in planning actions to fill gaps in these areas within these countries.

Originality / Value: This study provides the necessary inputs to support decision-making in strategic public policymaking actions that encourage the promotion of skills needed for the current stage of the sustainable competitiveness of nations.
\end{abstract}

Keywords:Additional BRICS; Global Human Capital Report; Global Innovation Index; Multicriteria; Economic development. 
Brazilian Journal of Operations \& Production Management

Volume 16, Número 4, 2019, pp. 659-671

DOI: 10.14488/BJOPM.2019.v16.n4.a11

\section{INTRODUCTION}

The developing countries, as a result of the globalization process, began to worry about the production and development of advanced technology since they became the stock and quality of Human capital, as well as inventions and innovations, determining factors for the allocation of international capital (Czajkowski et al., 2013).In proportion to the financial investments in these countries, the demand for personnel trained to successfully handle foreign operations has increased (Tung, 2016).

When, in 2001, economist Jim O'Neill, of Goldman Sachs Investment Bank, ideated the BRIC acronym, he referred to the emerging countries that pointed, that year, to an accelerated economic growth: Brazil, Russia, India and China. More precisely, it was prevised that China and India would become poles in the supply of manufactured goods and services while Brazil and Russia would be dominant suppliers of raw materials,taking into account that, at the time, the Gross Domestic Product (GDP) growth in the four countries represented $8 \%$ of the world GDP. The BRIC question, developed by the economist, that the four countries would reform their political and economic systems to adopt global capitalism has been recognized until today (Chenget al., 2007).

Lined up with this new economic perspective, since 2006 several Summits have been taking place between countries (Table 1), aiming to reach common points of agreement, both in relations between them, through bilateral agreements, and in the development of means to assist public and private institutions of their respective countries to better face the global market, such as the creation of the Network University in 2015 and the Plan for Cooperation in Innovation in 2017. Based on this discussion, Coulibaly et al. (2018) postulate that policies aimed at innovation will promote trade agreements and sustain economic development in emerging countries.

For the X Summit, held in South Africa, the leaders of Argentina, Jamaica, Turkey and Indonesia were invited to attend, and some of the topics discussed were the issues of industrialization and new technologies, based on the project called "Additional BRICS", which aims to increase cooperation among emerging countries for common prosperity in the era of the Fourth Industrial Revolution (Brasil, 2018).

In his Forbes article, Skroupa (2017) states that "The turn of the $21^{\text {st }}$ century has redefined innovation once more in the global economy, as thought leaders have been driven by the goal of gaining a competitive advantage through human capital".Debrah et al. (2018) argue that, by investing in the development of their human capital, the organizations improve their capabilities, leading them to innovations and generation of sustained international competitiveness.
In relation to the importance of investments in Human Capital and Innovation, the World Economic Forum (WEF) (available at www.weforum.org/reports) and the World Intellectual Property Organization (WIPO) (available at www. wipo.int/publications/en/) publish the results of country performance assessments in these areas at a global level in their annual reports, providing a snapshot of each country's position vis-à-vis the global context. The Global Human Capital Report (GHCR) and the Global Innovation Index (GII), presented by the WEF and WIPO, are relevant for the generation of a comparative structure of the performance of these countries in relation to sustainable global competitiveness (Saisse, 2018).

Within this approach, in order to analyze which member has the best conditions to face the challenges of the global market with the BRICS group, the TOPSIS method (Technique for Ordering Preference by Smile to the Ideal Solution) was adopted in this study, supported by Pavan and Todeschini's assertion (2016) that problems with multicriteria decisions refer to the decision making that involves the selection of the best alternative among two or more potential alternatives, often dealing with problems where alternatives can be complex and conflicting. Added to this is the position of Santis et al. (2017) where the multicriteria decision methods (MCDM) have to evaluate several alternatives in the face of multiple criteria in an environment surrounded by uncertainties. And it is supported by Silva et al. (2010), who show that, "Given the complexity of the decision-making process, it is advantageous to have a decision support system that guarantees transparency, speed and, above all, a structured analysis of the problem, incorporating all aspects of the situation."

Survey conducted in the Scopus database without time delimitation significantly substantiates the applicability of TOPSIS to decision-making on issues involving Human Capital and Innovation, where twenty-two articles on the themes cited in this paper have been found. As to the theme human capital, Rahimniaet al. (2017) compare the performance of civil servants in a province of Azerbaijan; Karbasianet al. (2016) use TOPSIS to define which of the departments of Malek-Ashtar University of Technology in Iran is the most efficient in human capital management; Balcerzak (2016) assesses the quality of human capital in the EU countries at the macroeconomic level; and Ding and Zeng (2015) measure the performance of 68 Chinese universities in the development of human capital. Concerning to the innovativeness and use of the method, Gupta and Barua (2016) propose a way to select suppliers among Small and Medium Enterprises in India, based on their Green innovation skills; Kavilal et al. (2016) propose the use of the method to delimit complexity factors in a supply chain; Fatih et al. (2015) employ the method in constructing a framework to help Indonesian government institutions choose the ideal cloud deployment model; Liu and Bai 
(2015) use the method to evaluate various aspects used in the construction of intelligent cities and thus to build a viable and practical evaluation system for their builders; and Chen and Chen (2010) built a system for Taiwanese higher education institutions to assess their performance in innovation. Still on the Scopus database, in research carried out with the TOPSIS themes, Human Capital and Innovation, simultaneously, no articles were found, thus highlighting the originality of this study for the generation of knowledge in the academic/scientific environment. It is also emphasized the importance of this study by providing resources to support decision making in the planning of strategic actions that encourage the current stage of the competitiveness of nations, thus filling a gap in these contexts. It should be noted that this research is established in the area of Operational Research (OR) called Decision Aid (DA), focusing on tools to aid decision making in processes that involve multiple alternatives and criteria.

In this sense, the systematic proposed in the present study is to comparatively analyze which countries have the best and the worst performance in the level of Human Capital valorization and results in Innovation, with the support of the primary data available in the annual reports on the countries invited to participate in the "Additional BRICS" project, and using a multicriteria decision support tool. The goal is to include themes, such as industrialization and new technologies, among others, in the agenda of the $X$ Summit.

This study is organized in five sessions: the first section presents the Introduction; the theoretical reference is described in the second section; in the $3^{\text {rd }}$ section the Methodology with the research framework is presented; in the $4^{\text {th }}$ section, the results demonstration and; finally, the $5^{\text {th }}$ session with the conclusions and possible lines of future research.

\section{THEORETICAL REFERENCE}

\section{The International Agreement of the BRICS Nations and the so-called BRICS Additional}

The first formal foreign ministerial meeting in Yekaterinburg in 2009 officially marked the BRIC institution, which was no longer an acronym used to identify the four rising countries in the international economic order to become a political-diplomatic entity. With the incorporation of South Africa during the meeting of BRIC foreign ministers in 2010 and later, with the formalization of this new member at the $3^{\text {rd }}$ Group Summit in China in 2011, the acronym was modified to BRICS (Reis, 2013).
Table 1. Historyof BRICS formation

\begin{tabular}{|c|c|c|}
\hline PERIOD & EVENT & LOCATION \\
\hline 2001 & Acronym coined by economist Jim O'Neil & USA \\
\hline 2006 & $\begin{array}{l}\text { Beginning of the integration process at } \\
\text { the 61st United Nations General Assembly } \\
\text { between the Foreign Ministers of the BRIC }\end{array}$ & USA - UN \\
\hline 2009 & I Summit & Russia \\
\hline 2010 & $\begin{array}{l}\text { II Summit - Accession of South Africa as an } \\
\text { effective member } \\
\text { Approval of the Brazilian Academic Forum }\end{array}$ & Brazil \\
\hline 2011 & $\begin{array}{l}\text { III Summit - Creation of the Technical } \\
\text { Group Science, Technology and Innovation }\end{array}$ & China \\
\hline 2012 & $\begin{array}{l}\text { IV Summit - Launch of the bases for the } \\
\text { BRICS Bank }\end{array}$ & India \\
\hline 2013 & $\begin{array}{l}\text { V Summit - Creation of the Business } \\
\text { Council }\end{array}$ & $\begin{array}{l}\text { South } \\
\text { Africa }\end{array}$ \\
\hline 2014 & $\begin{array}{c}\text { VI Summit - Creation of BRICS Bank - } \\
\text { Headquarters in China with initial capital of } \\
\text { US } \$ 50 \text { Billion }\end{array}$ & Brazil \\
\hline 2015 & $\begin{array}{c}\text { VII Summit - Creation of the University in } \\
\text { Network }\end{array}$ & Russia \\
\hline 2016 & $\begin{array}{l}\text { VIII Summit- Creation of the BRICS Cus- } \\
\text { toms Committee }\end{array}$ & India \\
\hline 2017 & $\begin{array}{l}\text { IX Summit - Creation of the Action Plan for } \\
\text { Innovation Cooperation 2017-2020 }\end{array}$ & China \\
\hline 2018 & X Summit - BRICS Project Additional & $\begin{array}{l}\text { South } \\
\text { Africa }\end{array}$ \\
\hline
\end{tabular}

Baumann (2013) understands that the BRICS group countries are taking shape in a process "[...] of alignment, which tends to share common causes when it comes to the need to convert a growing economic power into a political capacity to influence the decisions on those issues that have global implications."

Prado (2014), in turn, argues that the grouping constitutes a relevant political body to act in the international scenario and with the objective of promoting joint actions for economic, social and strategic development.

Mezentceva and Mezentceva (2017) understand that the construction of an entrepreneurial policy between the groupings can be elaborated from the exchange of the specialized knowledge existing in each country, favoring the economic development of the bloc.

Equally relevant is the fact that in the first decade of the twenty-first century the five countries accounted for $27.8 \%$ of the world GDP growth in nominal terms or $36.6 \%$ in purchasing power parity (Stuenkel, 2015). Such a brand, according to Coulibaly et al. (2018), has been achieved because the BRICS group is at the forefront of emerging countries, following rapid global growth and not having faced so many economic challenges before and after the US financial crisis in 2008/2009. 
It should be noted that the group made up by the countries with great perpectives of economic growth, at the time of its integration, now represents $29.4 \%$ of the world's territory, $41.2 \%$ of the global population and with Foreign Direct Investment (FDI) totaling US\$ 266.4 Billion (table 2).

Since the original BRICS group was formed by countries from four different continents, among the countries invited to participate in the BRICS project there are also four additional geographically separated and culturally distinct countries with political views of development influenced by the continents to which they belong:

- The island of Jamaica, with a strong tourist appeal, attracts millions of visitors to its beaches and is a major exporter of bauxite ( $4^{\text {th }}$ largest producer in the world);

- Turkey is a country whose geographical locationis both politically and economically strategic because it is situated between two blocks of economically and culturally distinct countries, Europe and the Middle East (Figure 1), suffering strong influences from both. Even today, despite institutional uncertainties, it is considered a medium-high income country;

- Indonesia is a country comprised of the seventeen-thousand-island conglomerate, rich in natural resources and one of the leading innovators among emerging low-income countries;

- Argentina, neighboring Brazil, is a nation rich in natural resources, with a highly literate population, export-oriented agriculture and a diversified industrial sector. In view of troubled governments and economic crises, it was downgraded by the World Bank high-income to middle-high income in 2016 (CIA, 2018).
A comparison of the socioeconomic indicators of the four countries, shown in table 3 below, reveals the level of foreign investment in Indonesia, thus justifying its position as an innovative country among low-income emerging countries.

It is based on Hussain and Hussain (2016), when they infer that the countries with the best human capital are likely to grow faster and the increase of the growth rate, in turn, will motivate the inflow of Foreign Direct Investment (FDI).

\section{The Global Human Capital and Innovation Indices}

For Lonska and Mietule (2015) the concept of HC is basically related to the way individuals make their economic choices in order to accumulate knowledge that, consequently, will increase their productivity and income, thus increasing the productivity and income of the country. Therefore, the authors affirm that the society investing in education and skills development will receive the desired economic return.

According to Stroombergen et al. (2002), Czajkowski et al. (2013) and Tung (2016) human capital development is directly intertwined with the development of sustainable competitiveness at the national level.

For The Global Human Capital Report - GHCR (WEF, 2017) people's skills are like a dynamic well-developed asset that will produce returns if they are invested optimally from the beginning of life, just as it will depreciate if not upgraded. Investment in formal education, maximizing opportunity for all, will improve people's ability to learn new skills and develop at work. Knowledge, talents and skills are, admittedly, the drivers for a thriving and inclusive economy.

Table 2. Socioeconomic data of BRICS

\begin{tabular}{|c|c|c|c|c|c|c|c|}
\hline Country & $\begin{array}{l}\text { Land area } \\
\left(1000 \mathrm{~km}^{2}\right)\end{array}$ & $\begin{array}{c}\text { Population } \\
\text { (million) }\end{array}$ & $\begin{array}{l}\text { Public Expendi- } \\
\text { tures with Educa- } \\
\text { tion (\% GDP) }\end{array}$ & $\begin{array}{c}\text { GDP } \\
\text { (Billions } \\
\text { US\$) }\end{array}$ & $\begin{array}{c}\text { Life } \\
\text { expectancy }\end{array}$ & $\begin{array}{c}\text { Population } 25-54 \\
\text { years old with } \\
\text { Tertiary Education }^{1}\end{array}$ & $\begin{array}{c}\text { FDI } \\
\text { (Billions US\$) } \\
2017 \\
\end{array}$ \\
\hline Brazil & 8,516 & 204 & 6.0 & 1,796 & 75.4 & 10.2 & 63 \\
\hline Russia & 17,125 & 146 & 3.9 & 1,286 & 71.4 & 29.8 & 25 \\
\hline India & 3,287 & 1,254 & 3.8 & 2,273 & 66.1 & 10.7 & 40 \\
\hline China & 9,600 & 1,371 & 1.9 & 11,203 & 76.3 & 8.4 & 136 \\
\hline South Africa & 1,221 & 55 & 6.0 & 295 & 62.5 & 13.7 & 2,4 \\
\hline
\end{tabular}

Source: The World Factbook (CIA, 2018) and Global Human Capital Index ${ }^{1}$ (WEF, 2017); 


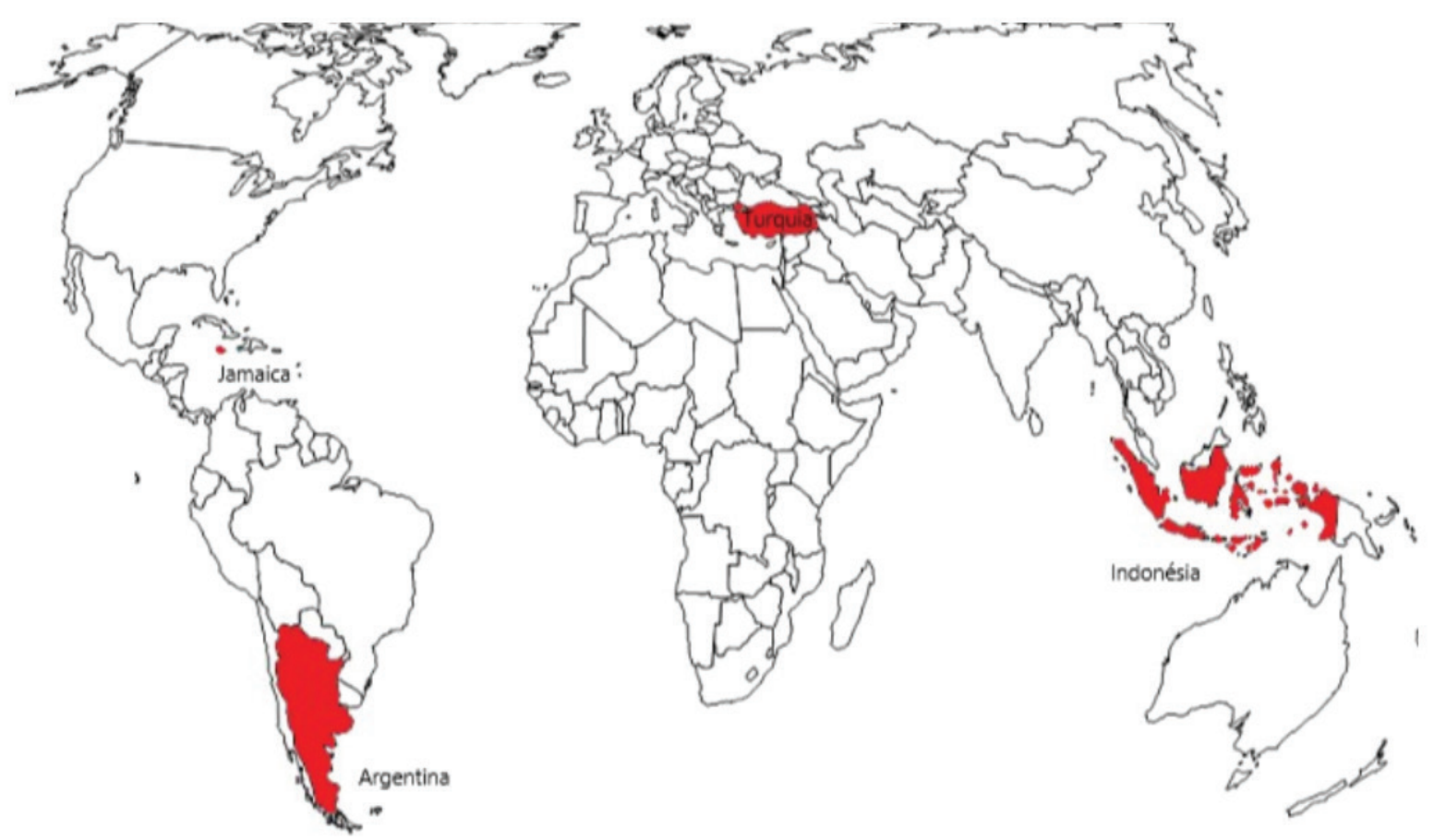

Figure 1. Location of the four countries invited to BRICS Additional

Source: Author

Table 3. Socioeconomic data of the invited countries.

\begin{tabular}{|c|c|c|c|c|c|c|c|}
\hline Country & $\begin{array}{c}\text { Land area } \\
\left(1000 \mathrm{Km}^{2}\right)\end{array}$ & $\begin{array}{c}\text { Population } \\
\text { (million) }\end{array}$ & $\begin{array}{c}\text { Public Expendi- } \\
\text { tures with Educa- } \\
\text { tion (\% of GDP) }\end{array}$ & $\begin{array}{c}\text { GDP } \\
\text { (Billions } \\
\text { US\$) }\end{array}$ & $\begin{array}{c}\text { Life } \\
\text { expectancy }\end{array}$ & $\begin{array}{c}\text { Population 25-54 } \\
\text { years old with } \\
\text { tertiary Education }\end{array}$ & $\begin{array}{c}\text { FDI } \\
\text { (Billions US\$) } \\
2017\end{array}$ \\
\hline Argentina & 2,780 & 44,293 & 5.3 & 920 & 77,3 & 17.5 & 84,14 \\
\hline Indonesia & 1,905 & 260,581 & 3.6 & 3,243 & 73 & 11.1 & 247,7 \\
\hline Jamaica & 11 & 2,991 & 5.5 & 26 & 73,7 & 10.9 & 15,03 \\
\hline Turkey & 784 & 80,845 & 4.8 & 2,173 & 75 & 12.2 & 143,7 \\
\hline
\end{tabular}

Source: The World Factbook (CIA, 2018) and Global Human Capital Index ${ }^{1}$ (WEF, 2017);

Adapted by Author

In line with this, the GHCR evaluates countries on the basis of results rather than inputs or means. The objective is to provide a snapshot of a country's current human capital, current investment in building future human capital, and current labor market outcomes, ranking countries on a scale of 0 to 100 in four thematic dimensions: Capacity, as it quantifies the current level of education of the population; Deployment, which measures how many segments of the population are able to participate in the labor force (men, women, youths and old people); Development, which measures the country's efforts to educate, empower and enhance the student body and the working-age population and Know-How that captures the breadth and use of skills at work, totaling 21 indicators.

The data provided by international organizations, such as the International Labor Organization (ILO) and the United Nations Educational, Scientific and Cultural Organization
(UNESCO) are collected and compiled for the composition of $\mathrm{GHCl}$ indicators. In addition, the Index uses qualitative research data from the World Economic Forum Executive Opinion Survey, expressed as percentages ranging from 0 to 100 percent. All these data are then standardized and weighted within each thematic dimension, generating values for each dimension that demonstrate the strengths and weaknesses of each country. The final result, pointing out the ranking in the 130 countries analyzed part from the simple average of these four values, used in this case as indicator for this study.

Surveys that point the index as a measure to capture and track the state of human capital development worldwide grounded the adoption of the Index in this study.

Chang et al. (2016) use the index to propose that the level of terciary education employees, indicated in the IGCH, is the potential factor related to increased productivity; Torres 
et al. (2015) used the IGCH to measure why the Brazilian population did not use e-government systems; Lonska and Mietule (2015) used the $\mathrm{GHCl}, \mathrm{HDI}$, and $\mathrm{GCl}$ indices to carry out an empirical analysis between the development of human capital and the level of development of nations; Nigri Musafir and de Freitas (2015) use the Online Index Service (OIS), e-participation Index, Telecommunication Infrastructure Index (TII), and Human Capital Index $(\mathrm{HCl})$ to analyze Brazil's position in the Government Development Electronic Index (GDEI); Alekseeva et al. (2014), using GHCl and GCl records, have developed theories for a better use of $\mathrm{HC}$, as a resource that contributes to the wealth and development of a country; Ali et al. (2013), after analyzing the Pakistani indicators in the $\mathrm{GHCl}$, understood that a better development of human capital will also attract substantial foreign investment, especially in developing countries.

In this way, when organizations foster the expansion of $\mathrm{HC}$ by supporting creativity and innovation, ensuring that these results circulate in the system will be promoting value creation (Saisse, 2014).

The innovation criterion, for Kaynaket al. (2017) is one of the main criteria for the economic superiority of the countries, in the elaboration of high technology products and for the permanent stay in a global competitive economy.

According to Manuel Castells, in his book The Rise of the Network Society (2010), what characterizes the technological advance is not the centrality of knowledge and information, but the application of such knowledge to the generation of knowledge and processing of information in a cumulative cycle of experiences.

In this sense, The Global Innovation Index (GII) is based on surveys that measure 127 countries in the field of innovation. The GII general score is a simple average of the scores of the two sub indices that comprise it: Inputs for Innovation and Product Innovation, that is, the input (conditions that favor innovation) and the output (economic and technological results) of the national system.

The Input - metric composed of Environment, Human Capital, Infrastructure, Market, and Company Sophistication; and the Output - metric composed by Knowledge Production and Technology and by the Generation of Creative Products (WIPO, 2017).These two sub-indices are composed of seven pillars (five linked to the Input sub-index: Institutions, Human Capital and Research, Infrastructure, Market Sophistication, and Business Sophistication; and two to Output sub-index - Knowledge and Technology Outputs and Creative Outputs). The GII (WIPO, 2017) shows us that "[...] each pillar is divided into three sub-pillars and each sub-pillar consists of two to five individual indicators. [...] Each pillar score is calculated from the weighted aver- age of the sub-pillar scores." Resulting in a total of 81 data indicators.

In addition to the classification of countries within this score, WIPO also assigns a classification called Efficiency Rate to countries, which is the ratio from output to input.

The data are collected from international organizations, such as the World Intellectual Property Organization (WIPO), the International Energy Agency, the United Nations Educational, Scientific and Cultural Organization (UNESCO), the United Nations Industrial Development Organization (UNIDO), International Telecommunication Union (ITU); and the Joint Research Center (JRC) of the European Commission, as well as private organizations, such as the International Organization for Standardization (ISO), IHS Global Insight, Quacquarelli Symonds Ltd, Bureau van Dijk (BvD), ZookNIC Inc. and Google.

Research that points to GII as a rich data set for comparative innovation analysis between organizations and nations, characterizing the conditions of the development of innovative investments from different perspectives, helped supporting the adoption of the Index in this study.

Jankowska et al. (2017) use the GIl to prove that the greater the innovation input, the greater the country's innovative output. Couto e Silva et al. (2017) use the GIl pillars related to human factors, to identify gaps and to assist the analysis of decision on investments in the area, by the National Innovation Systems; Prim et al. (2017) analyze a correlation between the intrinsic values of a national culture and the its favoring in the development of innovationfor nations and organizations; Crespo and Crespo (2016) through the comparative analysis of GII indicators, postulate that a country can achieve better innovative performance through various facilitator combinations - innovation input; Sohn et al. (2016) use the GII in the observation of the innovative capacity and the level of efficiency of the countries analyzed by the index; Shayan et al. (2015) are based on the GII to demonstrate that the media can be a strong lever of innovation and economic development; Solozhentsev (2015) is based on the GII to explore the impact of corruption and its relation to economic development; Alfantookh and Bakry (2015) are concerned with "[...] investigating the state of innovation in the Persian Gulf countries in order to allow the development of future plans that promote innovation [...]"; Nair et al. (2014) analyzes the production of innovation in the United Arab Emirates with the support of a neural regression network and the GII; Rullan et al. (2012), using the GII, show that an economy based on innovation is fundamental to boost competitiveness in Latin America.

According to Autant-Bernard et al. (2010), innovation has proven to be the driving force for sustainable economic 
growth in countries that exploit and implement technological capabilities by bringing prosperity to its highest levels.

\section{METHODOLOGY}

\section{The TOPSIS Method}

TOPSIS is a multicriteria decision-making technique developed by Hwang and Yoon (1981), whose principle is to define, by similarity, the alternative that is closer to the positive ideal solution (PIS) and which is further from the negative ideal solution (NIS), thus generating an order for analysis, within the chosen criteria, to be applied, in this case, to the countries of Argentina, Jamaica, Turkey and Indonesia.

The work will be presented using a multicriteria decision analysis method (MCDA), applied to the context of the countries Argentina, Indonesia, Jamaica and Turkey as alternatives and adopting as criteria the Global Human Capital Index and the Global Innovation Index, published in the period from 2015 to 2017 by WEF and WIPO.

Therefore, the TOPSIS algorithm is developed in the following steps proposed by Hwang and Yoon (1981):

$1^{\text {st }}$ - Construction of the Decision Matrix - Initially, the matrix is assembled from the data obtained with the selected alternatives $(\mathrm{m})$ and criteria $(\mathrm{n})$;

$$
A=\quad \begin{aligned}
& A_{1} \\
& \quad
\end{aligned} \quad\left\{\begin{array}{ccc}
C_{1} C_{2} & \ldots & C_{n} \\
x_{11} x_{12} & \ldots & x_{1 n} \\
\vdots & \ldots & \vdots \\
x_{m 1} x_{m 2} & \ldots & x_{m n}
\end{array}\right\}
$$

$2^{\text {nd }}$ - Calculation of the Normalized Matrix - Once the values are obtained, they are transformed into equal scales in order to allow comparisons between the attributes. In this work the normalization formula by vector was used;

$$
r_{i j}=\frac{x_{i j}}{\sqrt{\sum_{i=1}^{m} x_{i j}^{2}}}
$$

$3^{\text {rd }}$ - Determination of weights for each criterion - Hwang and Yoon (1981) in developing TOPSIS, show us that problems involving Multiple Criteria Decision Making require more information regarding the relative importance of each attribute. Such importance is generated through a series of weights that, when normalized, its sum must be equal to 1 .

The two researchers cite the existence of various techniques for collecting Decision Makers a weight value for each criterion; however, they give preference to the use of other methods "[...] to substitute a small (single) statistical sample for a large one",where, among others, they use Entropiato determine weights, including the formula used by Zeleny (1974).

According to Sarraf et al. (2013) Entropia was created by Shannon (1948) within what would be called Information Theory, where the method would be used to measure the weight of information, that is, to measure the degree of information contained within a certain message. Hwang and Yoon (1981) verified that the decision matrix also contains a certain amount of information and saw the entropy as a tool to evaluate the criteria and calculate the weight of the data contained therein.

Barba-Romero (1998) understands that in the decisions of problems involving Multicriteria, the attribution of the relative weights for each criterion, according to specialists or to the decision maker, will bring some subjectivity to the process, the Entropy being, in his opinion, of great advantage in view of its objectivity in cases of decisions involving varied data.

Corroborating this understanding, Sun and Ouyang (2015) propose the weight method based on entropy to assign weights alternatives when these are completely unknown and inaccurate, stating that this is a way of dealing with the imprecision of judgments by enabling objectivity in the attributions of the alternatives.

In light of these facts, Zeleny's (1974) Entropy formula was used to apply the relative importance to each year of each criterion for application in the normalized matrix:

$$
e_{j}=-\frac{1}{\ln (m)} \sum_{i=1}^{m} P_{i j} \ln \left(p_{i j}\right)
$$

Where $m$ is the total number of alternatives, $i=1 \ldots . n$ and $\mathrm{j}=1 . . \mathrm{m}$ shown in the first step. The degree of diversity for each criterion is calculated according to $d_{j}=1-e_{j}$. The weight of each criterion is then determined by:

$$
W j=\frac{d_{j}}{\sum_{j=1}^{n} d_{j}}
$$

And, finally, the normalized matrix values are multiplied by the weight:

$$
V_{i j}=W_{j}^{*} p_{i j}
$$

$4^{\text {th }}$ - Identification of PIS (positive ideal solution) and NIS (negative ideal solution) - In the new generated matrix 
an attempt is made to identify each of the ideal (PIS) and non-ideal (NIS) alternatives in each criterion;

$5^{\text {th }}$ - Calculation of the Euclidean distances - the distance in relation to the ideal (D+) and non-ideal (D-) solution is calculated for each value, in the criteria, obtained in the normalized and wheighted matrix.

$$
D_{i}^{+}=\sqrt{\sum_{j=1}^{n}\left[v_{i j}(x)-v_{j}^{+}(x)\right]^{2} D_{i}^{-}}=\sqrt{\sum_{j=1}^{n}\left[v_{i j}(x)-v_{j}^{-}(x)\right]^{2}}
$$

Where is $v_{j}^{+}(x)$ equal to PIS and $v_{j}^{-}(x)$ is equal to NIS.

Consequently, the coefficient $\mathrm{C}$ is calculated, resulting in the approximation to the ideal positive situation;

$6^{\text {th }}-$ Calculations of the coefficients C: For each of the alternatives $D+$ and $D$ - associated with a criterion, determine a coefficient $C$ from the formula $C=D-/(D-+D+)$. $7^{\text {th }}$ - Sorting of the alternatives -Ranking generation in ascending order.

The literature review shows that such a tool has already been applied successfully to solve evaluation problems in a finite range of alternatives (Shih et al., 2007).

\section{Modeling of similarity with solution ideal for ordering Countries}

For the proposed modeling, a decision matrix was defined, where the four countries invited to participate in the project were chosen as alternatives: Argentina, Jamaica, Indonesia and Turkey.And in this concept, the values of the total scores provided for each country mentioned above by the Human Capital and Innovation Indices were considered as criteria, based on the reports made available respectively by WEF (WEF, 2015, 2016, 2017) and WIPO (WIPO, 2015, 2016, 2017), in the period from 2015 to 2017. Table 5 is then created with the two criteria, subdivided over the three year period (2015 to 2017), with respective country indicators measuring the alternatives.

Table 5. Decision Matrix

\begin{tabular}{|c|c|c|c|c|c|c|}
\hline Dimension & \multicolumn{3}{|c|}{ GHCI } & \multicolumn{3}{c|}{ GII } \\
\hline Country & $\mathbf{2 0 1 5}$ & $\mathbf{2 0 1 6}$ & $\mathbf{2 0 1 7}$ & $\mathbf{2 0 1 5}$ & $\mathbf{2 0 1 6}$ & $\mathbf{2 0 1 7}$ \\
\hline Argentina & 71.01 & 70.70 & 64.34 & 34.30 & 30.20 & 32.00 \\
\hline Jamaica & 65.95 & 68.62 & 58.39 & 29.90 & 29.00 & 30.36 \\
\hline Indonesia & 66.99 & 67.61 & 62.19 & 29.80 & 29.10 & 30.10 \\
\hline Turkey & 67.09 & 67.61 & 60.33 & 37.80 & 39.00 & 38.90 \\
\hline
\end{tabular}

Source: Author

Table 6. Normalized Matrix

\begin{tabular}{|c|c|c|c|c|c|c|}
\hline Dimension & \multicolumn{3}{|c|}{ GHCI } & \multicolumn{3}{c|}{ GII } \\
\hline Country & $\mathbf{2 0 1 5}$ & $\mathbf{2 0 1 6}$ & $\mathbf{2 0 1 7}$ & $\mathbf{2 0 1 5}$ & $\mathbf{2 0 1 6}$ & $\mathbf{2 0 1 7}$ \\
\hline Argentina & 0.0869 & 0.0854 & 0.0870 & 0.0866 & 0.0790 & 0.0810 \\
\hline Jamaica & 0.0807 & 0.0829 & 0.0789 & 0.0755 & 0.0759 & 0.0769 \\
\hline Indonesia & 0.0819 & 0.0816 & 0.0841 & 0.0752 & 0.0762 & 0.0762 \\
\hline Turkey & 0.0821 & 0.0816 & 0.0816 & 0.0954 & 0.1021 & 0.0985 \\
\hline
\end{tabular}

Source: Author

Table 7. Identification of ideal and anti-ideal solution

\begin{tabular}{|c|c|c|c|c|c|c|}
\hline $\begin{array}{c}\text { Period } \\
\text { Solution }\end{array}$ & $\mathbf{2 0 1 5}$ & $\mathbf{2 0 1 6}$ & $\mathbf{2 0 1 7}$ & $\mathbf{2 0 1 5}$ & $\mathbf{2 0 1 6}$ & $\mathbf{2 0 1 7}$ \\
\hline PIS & 0.0869 & 0.0854 & 0.0870 & 0.0954 & 0.1021 & 0.0985 \\
\hline NIS & 0.0807 & 0.0816 & 0.0789 & 0.0752 & 0.0759 & 0.0762 \\
\hline
\end{tabular}


Table 8. EuclideanDistances

\begin{tabular}{|c|c|c|c|c|c|c|}
\hline Period & \multicolumn{2}{|c|}{2015} & \multicolumn{2}{c|}{2016} & \multicolumn{2}{c|}{2017} \\
\cline { 1 - 6 } Distances & \multirow{2}{*}{ D+ } & D- & D+ & D- & D+ & D- \\
\hline Country & 0.0088 & 0.0129 & 0.0231 & 0.0049 & 0.0175 & 0.0094 \\
\hline Argentina & 0.0209 & 0.0003 & 0.0263 & 0.0013 & 0.0231 & 0.0007 \\
\hline Jamaica & 0.0208 & 0.0012 & 0.0262 & 0.0003 & 0.0225 & 0.0052 \\
\hline Indonesia & 0.0048 & 0.0202 & 0.0038 & 0.0262 & 0.0054 & 0.0225 \\
\hline Turkey & & & & &
\end{tabular}

Source: Author

In order to compare the alternatives, the matrix is normalized, according to the method and with the assignments of the weights for the criteria, table 6 .

The table 7 presents the results obtained in the calculation of the ideal solution (PIS) and anti-ideal (NIS).

The results obtained in the calculation of the Euclidean distances for each country and the Coefficient $\mathrm{C}$ are shown respectively in tables 8 and 9.

Table 9. Coefficient C

\begin{tabular}{|c|c|c|c|}
\hline \multirow{2}{*}{ Period } & \multirow{2}{*}{$\mathbf{2 0 1 5}$} & $\mathbf{2 0 1 6}$ & $\mathbf{2 0 1 7}$ \\
\cline { 1 - 3 } Country & & & \\
\hline Argentina & 0.5938 & 0.1753 & 0.3508 \\
\hline Jamaica & 0.0121 & 0.0455 & 0.0291 \\
\hline Indonesia & 0.0564 & 0.0099 & 0.1876 \\
\hline Turkey & 0.8072 & 0.8742 & 0.8055 \\
\hline
\end{tabular}

The final rankings, with the alternatives arranged in ascending order, presenting the country with the best performance in the considered dimensions, are presented in tables 10,11 and 12 .

Table 10. Ranking in 2015

\begin{tabular}{|c|c|c|}
\hline \multirow{5}{*}{ 뭉 } & Country & Position \\
\hline & Turkey & $1 s t$ \\
\hline & Argentina & $2 n d$ \\
\hline & Indonesia & $3 r d$ \\
\hline & Jamaica & 4th \\
\hline
\end{tabular}

Table 11. Ranking in 2016

\begin{tabular}{|c|c|c|}
\hline \multirow{5}{*}{ 동 } & Country & Position \\
\hline & Turkey & 1st \\
\hline & Argentina & 2nd \\
\hline & Jamaica & $3 r d$ \\
\hline & Indonesia & 4th \\
\hline
\end{tabular}

Table 12. Ranking in 2017

\begin{tabular}{|c|c|c|}
\hline \multirow{4}{*}{$*$} & Country & Position \\
\cline { 2 - 3 } & Turkey & $1^{\text {st }}$ \\
\cline { 2 - 3 } & Argentina & $2^{\text {nd }}$ \\
\cline { 2 - 3 } & Indonesia & $3^{\text {rd }}$ \\
\cline { 2 - 3 } & Jamaica & $4^{\text {th }}$ \\
\hline
\end{tabular}

Source: Author

The ordering of the countries allows a better visualization of the efficiency of the method,demonstrating how the criteria approached for each alternative analyzed show the countries best placed from the themes discussed at the $X$ BRICS Summit, andChart 1 below represents the positioning achieved by the countries, based on their performance in Human Capital and Innovation evaluated and gathered during the period studied.

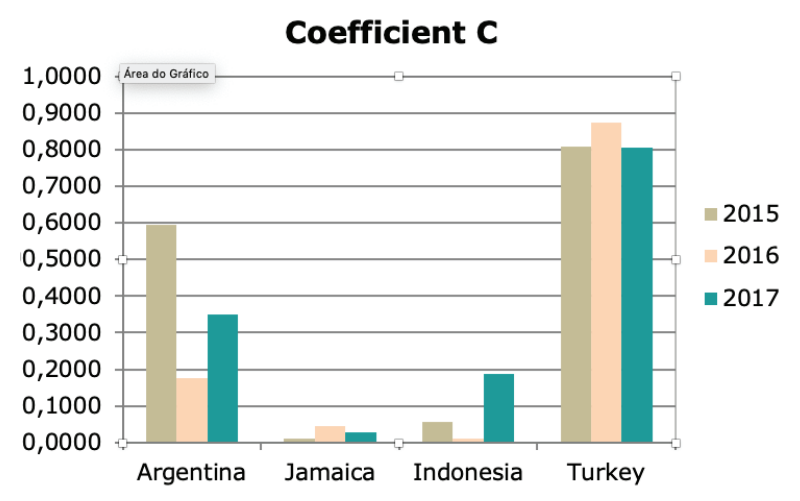

Chart 1. Positioning achieved by the Countries Source: Author

\section{RESULTS}

The modeling applied from the global indices of human capital and innovation allowed the greater perception of the context, as explained in the following graphs.Chart 2 , contextualizes Argentina as a country that presents a welltrained workforce, compared to other countries. According to the Global Human Capital Report, the two countries with the best performance in Human Capital in Latin America in 2017 are Argentina along with Chile. 
D Brazilian Journal of Operations \& Production Management Volume 16, Número 4, 2019, pp. 659-671

DOI: 10.14488/BJOPM.2019.v16.n4.a11
Still within this context, the graphical analysis allows highlighting the commitment made by the Indonesian government in improving the qualification of its work force during the period covered. Turkey has also done a good job of bringing quality education to new generations, but culture is still seen as a hindrance to influencing gender issues in the use of this workforce.

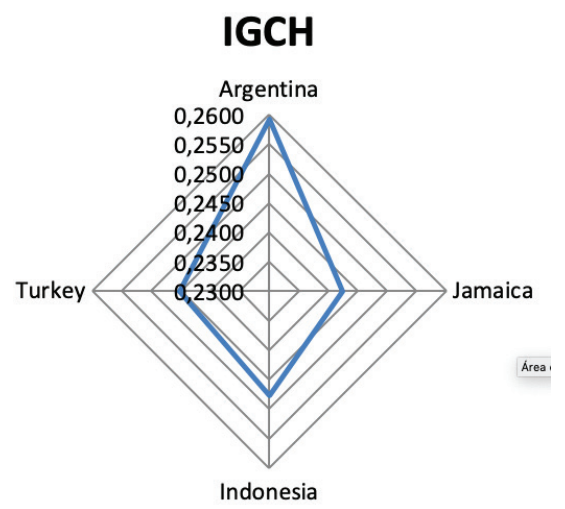

Chart 2. Demonstration of Human Capital Source: Author

The evaluation related to Innovation generated Chart 3 , which presents another aspect. In it, Turkey showsitself more competitive in terms of innovation due to its good result in the calculation of the efficiency rate for innovation, which is made due to the existing conditions in the countryfavoring innovation and the results of innovative activities, such as the production of knowledge, technology and creative productions as determined by GII, which places Turkey among the 10 most efficient countries (Table 13).

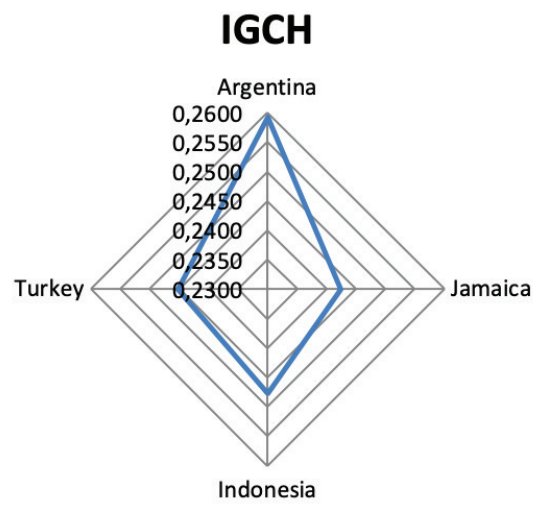

Chart 3. DemonstrationofInnovation Source: Author

Argentina, on the other hand, shows an improvement due to the investments in R\&D, as portrayed in the WIPO report of 2017, stating that "[...] although advanced economies have historically been leaders in R\&D [...], research capacity has also reached high standards in a number of emerging economies (middle income), such as China, India, Brazil, Argentina, and South Africa."

Table 13. InnovationEfficiency Ranking

\begin{tabular}{|c|c|c|}
\hline $\begin{array}{c}\text { Position in } \\
\text { Ranking }\end{array}$ & Country & $\begin{array}{c}\text { Knowledgeand } \\
\text { Technology Output }\end{array}$ \\
\hline 9 o & Turkey & 35.48 \\
\hline $42 \circ$ & Indonesia & 24.52 \\
\hline $86 \circ$ & Jamaica & 22.03 \\
\hline $94 \circ$ & Argentina & 22.68 \\
\hline
\end{tabular}

Source: The Global Innovation Report 2017 - Adapted by the author

According to the same report, Indonesia is pointed out as one of the leading innovators among low-income emerging countries, only failing to achieve better ranking results due to internal factors, such as low-income population, strong dispersion of its inhabitants, and low readiness for innovation use.

It is highlighted that, according to the BRICS Innovative Competitiveness Report 2017 (Zhao et al., 2018), innovation plays the role of driving force for the development of sustainability in the world, promoting economic growth, generating jobs new businesses and structural reforms, bringing greater productivity and competitiveness, bringing improvements in the delivery of services to society, and directing challenges,Thus informing that "the BRICS countries seek to encourage innovation through practical action to promote sustainable economic growth today and lay a solid foundation for the future."

\section{CONCLUSION}

The development of this research has comparatively evidenced the positions of the countries Argentina, Indonesia, Jamaica, and Turkey in relation to their Human Capital and Innovation indicators in the global context, as they were invited to participate in the "Additional BRICS" Project, which brings the issues of new technologies and industrialization to discuss the cooperation between them and the current BRICS.

The multicriteria decision analysis method, TOPSIS (Technique for Order of Preference by Similarity to Ideal Solution) was used as a tool for analysis and comparison of the indicators used to measure the performance of these countries in relation to the issues of the $X$ Summit mentioned above.

Through the method, results were obtained in terms of total Human Capital and Innovation values, where the four invited emerging countries show populations with almost equal values in their knowledge capacities $(\mathrm{GHCl})$, but with a strong differential to the innovation factor (GII). 
The analysis revealed that, among the dimensions considered for the alternatives, the most ideal solution within the BRICS Additional Project referred to Turkey is evidenced in the Human Capital and Innovation questions (Chart 1) to meet what is considered to be the pressing interests of BRICS Original competition in the global market.

Jamaica ranks last when it comes to Innovation in the face of low $R$ \& $D$ investment and training of its university centers, making it difficult to compete competitively in the global market. Added to this is the fact that the country has a low level of general third-level training (only $5 \%$ with tertiary level).

Turkey is very innovative as it brings innovation to its production lines. Argentina also appears well placed on the chart, in view of public and private R \& D expenditures.

The recent treaties established among the BRICS nations concerning capacity building in these sectors will undoubtedly be of great help to these four nations in the quest for greater competitiveness on the global stage, as it is believed that such alliances or collaborative connections extend beyond the boundaries between nations.

This research was limitedby the scenario of the emerging BRICS countries and the countries invited to the $X$ Summit, as well as the limitation of the two $\mathrm{GHCl}$ and $\mathrm{GII}$ indicators selected to compose the systematic proposal. However, it is believed that this study has provided grants to support decision-making in strategic actions for the formulation of public policies that encourage the promotion of skills necessary to the current stage of the competitiveness of nations. As a major suggestion for future research, it is recommended to apply the method to other global indicators reported by WEF and other international economic/social performance analysis bodies for a broader understanding of the behavior of these countries.

\section{REFERENCES}

Alekseeva, L. V. et al. (2014) "Institutional traps of human capital consumption: Public goods production problems", Mediterran Journal of Social Sciences, Vol. 5, No. 24.

Alfantookh, A; Bakry, S. H. (2015) "Investigation of the state of innovation in the Gulf Cooperation Council countries: Looking ahead", Computers in Human Behavior, Vol. 48.

Ali, H. et al. (2013) "Human capital as determinant of foreign direct investment (FDI) in Pakistan", Middle East Journal of Scientific Research, Vol. 17, No. 7.

Autant-Bernard, C. et al. (2010), "Measuring the adoption of innovation. A typology of EU countries based on the innovation survey", Innovation: The European Journal of Social Science Research, Vol. 23, No 3.
Balcerzak, A. P. (2016) "Multiple-criteria evaluation of human capital in the Europeian union countries", Economics and Sociology, Vol. 9, No 2.

Barba-Romero, S. (1998), “Conceptos y soportes informáticos de La decisión multicriterio discreta", In: Martínez, E. and Escudey, M. (Eds.), Evaluación y Decisión Multicriterio: Reflexiones y Experiencias, Universidad de Santiago de Chile.

Baumann, R. (2013), "The BRICS and the Financial G20", Brazil, The BRICS and the International Agenda, 2nd, FUNAG, Brasília.

Brasil (2018), "Next Brics summit will be held in July in South Africa", Brazilian Agency. Available from: http://agenciabrasil.ebc.com.br/internacional/noticia/2018-03/proxima-cupula-dos-brics-sera-realizada-em-julho-na-africa-do-sul (Accessed on July 12, 2018).

Castells, M. (2010), "The Rise of the Network Society", 2nd ed., Wiley-Blackwell.

Central Intelligence Agency (CIA), "The World Factbook". Available from: https://www.cia.gov/library/publications/resources/the-world-factbook/ (Accessed on: August 19, 2018).

Chang, C.-F. et al. (2016) "Knowledge spillovers, human capital and productivity", Journal of Macroeconomics, Vol. 47, Part B.

Chen, J. K. and Chen, I.-S. (2010), "Using a novel conjunctive MCDM approach based on DEMATEL, fuzzy ANP, and TOPSIS as an innovation support system for Taiwanese higher education", Expert Systems with Applications, An Internacional Journal, Vol. 37, No. 3, pp. 1981-1990.

Cheng, H. F. et al. (2007), "A future global economy to be built by BRICs", Global Finance Journal, Vol. 18, No. 2, pp. 143156.

Cornell University, INSEAD, WIPO. (2015), "The Global Innovation Index 2015: Effective Innovation Policies for Development", Fontainebleau, Ithaca, Geneva.

Cornell University, INSEAD, WIPO. (2016), "The Global Innovation Index 2016: Winning with Global Innovation", Ithaca, Fontainebleau, Geneva.

Cornell University, INSEAD, WIPO. (2017), "The Global Innovation Index 2017: Innovation Feeding the World", Ithaca, Fontainebleau, Geneva.

Coulibaly, S. K. et al. (2018). "Economic globalization, entrepreneurship, and development". Technological Forecasting and Social Change, Vol. 127, pp. 271-280.

Couto e Silva, E. et al. (2017) “A portfolio analysis methodology to inform innovation policy and foresight", Technological Forecasting and Social Change, Vol. 115.

Crespo, N. F.; Crespo, C. F. (2016) "Global innovation index: Moving beyond the absolute value of ranking with a fuzzy-set analysis", Journal of Business Research, Vol. 69, No. 11. 
Brazilian Journal of Operations \& Production Management

Volume 16, Número 4, 2019, pp. 659-671

DOI: 10.14488/BJOPM.2019.v16.n4.a11
Czajkowski, Z. et al. (2013). "Human capital and innovation: basic concepts, measures and interdependencies", in Weresa , M. A. (Ed.), Innovation, Human Capital and Trade Competitiveness: how are they connected and why do they matter? Springer Science \& Business Media, London.

Debrah, Y. A. et al. (2018). "Human Capital, Innovation and International Competitiveness in Sub-Saharan Africa", In: Adeleye, I.; Esposito, M. (eds), Africa's Competitiveness in the Global Economy, AIB Sub-Saharan Africa (SSA) Series. Palgrave Macmillan, Cham.

Ding, L.; Zeng, Y. (2015), “Evaluation of Chinese higher education by TOPSIS and IEW - The case of 68 universities belonging to the Ministry of Education in China". China Economic Review, Vol. 36, pp. 341-358.

Fatih, G. et al. (2015). "Framework for selecting cloud deployment model in government institutions using BCOR, entropy and TOPSIS approach". International Journal of Innovation and Learning (IJIL), Vol. 18, No. 1, pp. 81-100.

Gupta, H.; Barua, M. K. (2016). “Fuzzy AHP approach to prioritize enablers of Green supply chain management practices: A case study of automotive component supplier". Management Science Letters, Vol. 6, No. 7, pp. 487-498.

Hussain, F.; Hussain, S. (2016), "Determinants of Foreign Direct Investment (FDI) in Pakistan: Is China Crowding Out FDI Inflows in Pakistan?", Pakistan Development Review, Special Edition.

Hwang, C.-L.; Yoon, K. (1981). "Multiple Attribute Decision Making - Methods and Applications: A State-of-the-Art Survey",Lecture Notes in Economics and Mathematical Systems, Vol. 186, Springer-Verlag.

Jankowska, B. et al. (2017) "Efficiency of National Innovation Systems - Poland and Bulgaria in the Context of the Global Innovation Index", Comparative Economic Research, Vol. 20, No. 3.

Karbasian, M. et al. (2016), "Performance evaluation of education system with human capital approach by data envelopment analysis and TOPSIS-with a case study", International Journal of Management in Education, Vol. 10, No. 4.

Kavilal, E. G. et al. (2016). "An integrated Fuzzy AHP and Fuzzy TOPSIS for prioritizing supply chain complexity drivers", International Journal of Operations and Quantitative Management, Vol. 22, No. 1, pp. 39-51.

Kaynak, S. et al. (2017), "Comparing the innovation performance of EU candidate countries: an entropy-based TOPSIS approach", Economic Research-Ekonomskalstraživanja, Vol. 30, No. 1, pp. 31-54.

Liu, Y.; Bai, Z. (2015), "The study on smart city construction assessment based on TOPSIS - "The PRD city clusters" as the case", Metallurgical and Mining Industry - Polytechnical journal, No. 9, p. 416-421.
Lonska, J.; Mietule, I. (2015), "The impact of human capital development on the economic and social development of a country: empirical study", Environment Technology. Resources. Proceedings of the International Scientific and Practical Conference, Vol. 2, p. 174.

Mezentceva, O. V.; Mezentceva, A. V. (2017), “Macroeconomic factors, entrepreneurial performance and economic growth in emerging markets". World Review of Science, Technology and Sustainable Development, Vol. 13, No. 1.

Nair, H. et al. (2014) "Neural network modelling, simulation and prediction of innovation growth in United Arab Emirates (UAE)", Procedia Computer Science, Vol. 36.

Nigri Musafir, V. E.; de Freitas, C. S. (2015) “Brazilian e-government strategies", Proceedings of the European Conference on e-Government, Vol. 2015.

Pavan, M.; Todeschini, R. (2009) “Multicriteria Decision-Making Methods", In: Brown, S. D. et al. (Eds.), Comprehensive Chemometrics, Chemical and Biochemical Data Analysis, Vol. 1., Elsevier, p. 591-629. Available from: https://www.sciencedirect.com/science/article/pii/B9780444527011000387 (Accessed in: Jan 28, 2018).

Prado, M. A. R. (2014). "BRICS in the geopolitical perspective: a scientometric analysis of the period from 2001 to 2010". Dissertation - Master in Information Science, Paulista State University Júlio de Mesquita Filho, São Paulo, SP.

Rahimnia, F. et al. (2017), "Prioritising employee performance evaluation indicators based on a combined FAHP-TOPSIS approach to intellectual capital development". International Journal of Public sector Perfomance Management, Vol. 3, No. 3.

Reis, M. E. F. (2013). "BRICS: emergence and evolution". Available at: https:/geovest.files.wordpress.com/2013/01/ surgimento-e-evoluc3a7c3a3o-dos-brics.pdf (Accessed on: July 28, 2018).

Rullan, S. et al (2012). "Public procurement for innovation: Challenges and prospects for Latin America", 7th International Symposium on Management of Technology, Article number 6679543 .

Saisse, R. L. G. (2014), "Um instante de reflexão sobre o conhecimento", Revista de Villegagnon, Ano IX, No. 9, p. 133139.

Saisse, R. L. G. et al. (2018), "Application of an ADMC tool in the creation of the Sustainable Competitiveness Index in the BRICS countries", Paper presented in ENEGEP - XXVIII National Meeting of Production Engineering. Alagoas, Maceió, available at: https://callforpapers.galoa.com.br/br/realm/ enegep-2018/submissions/ 88008 (Accessed on: August 20, 2018).

Santis, R. et al. (2017), "Multi-criteria supplier selection using fuzzy analytic hierarchy process: case study from a Bra- 
zilian railway operator". Brazilian Journal of Operations \& Production Management, Vol. 14, No. 3.

Sarraf, A. Z. et al. (2013), "Developing TOPSIS method using statistical normalization for selecting knowledge management strategies". Journal of industrial Engineering and Management, Vol. 6, No 4.

Shannon, C. E. (1948). "The mathematical theory of communication", Bell System Technical Journal, Vol. 27.

Shih, H.-S. et al. (2007). "An extension of TOPSIS for group decision making". Mathematical and Computer Modeling, Vol. 45, No. 7-8.

Silva, V. et al. (2010), "Prioritizing Complex Issues of Hydrographic Basin Committees by Group Decision Approach", Brazilian Journal of Operations \& Production Management, Vol. 7, No. 1.

Skroupa, C. P. (2017) "Competitive Advantage - How Innovation Is Shaping The 21st Century Company", Forbes. available at: https://www.forbes.com/ sites/christopherskroupa/2017/10/04/competitive-advantage-how-innovation-is-shaping-the-21st-century-company/\#6d5803186a4c (Accessed on: October 4, 2017).

Sohn, S. Y. et al. (2016) "Re-evaluation of global innovation index based on a structural equation model", Technology Analysis and Strategic Management, vol. 24, No. 4.

Solozhentsev, E. D. (2015) "Logic and probabilistic risk models for management of innovations system of country", International Journal of Risk Assessment and Management, Vol. 18, No. 3-4.

Stroombergen, A. et al. (2002) "Review os Statistical Measurement of Human Capital", Statistics New Zealand.
Stuenkel, O. (2015), "The BRICS and the Future of Global Order", Lexington Books.

Sun, Q. P. and Ouyang, J. W. (2015), “Hesitant Fuzzy Multi-Attribute Decision Making Based on TOPSIS With Entropy-Weighted Method", Management Science and Engineering, Vol. 9, No. 3, pp. 1-6.

Torres, J. A. S. et al. (2015) "An analysis of the Brazilian challenges to advance in e-government", Conference: European Conference on eGovernment.

Tung, R. L. (2016), "New perspectives on human resource management in a global context", Journal of World Business, Vol. 51, No. 1.

World Economic Forum. (2015). "The Human Capital Report 2015", Cologny, Geneva, available at: http://reports.weforum.org/human-capital-report-2015 (Accessed on: December 02, 2017).

World Economic Forum. (2016). "The Human Capital Report 2016", Cologny, Geneva, available at: http://reports.weforum.org/human-capital-report-2016 (Accessed on: November 23, 2017).

World Economic Forum. (2017). "The Global Human Capital Report 2017: Preparing people for the future of the world",Cologny, Geneva, available at: https://www.weforum. org/reports/the-global-human-capital-report-2017/ (Accessed on: November 23, 2017).

Zeleny, M. (1974), "Linear Multiobjective Programming", Springer-Verlag, Berlin/Heidelberg/New York.

Zhao, X. et al. (2018), Innovative Competitiveness Report 2017, Springer, Singapore. DOI: 10.1007/978-981-10-8078-4

Received: 08 Sept 2018

Approved: 10 Jan 2019

DOI: 10.14488/BJOPM.2019.v16.n4.a11

How to cite: Saisse, R. L. G. and Lima, G. B. A. (2019), "Similarity modeling with ideal solution for comparative analysis of projects in the context of the additional brics proposal", Brazilian Journal of Operations \& Production Management, Vol. 16, No. 4, pp. 659-671, available from: https://bjopm.emnuvens.com.br/bjopm/article/ view/561 (access year month day). 